\title{
Case report of an adolescent girl with Kabuki syndrome and kyphoscoliosis, resistant at the conservative orthopedic treatment
}

\author{
MA Taranu*, M Colomer Giralt, V Calderón Padilla, V Pujol Blaya, L Quesada Morán, JM Cavanilles Walker, \\ BM Núñez García, C Rodríguez Monje
}

From 8th International Conference on Conservative Management of Spinal Deformities and SOSORT 2011

Annual Meeting

Barcelona, Spain. 19-21 May 2011

\section{Background}

The Kabuki syndrome (KS) is a rare genetic, hereditary, autosomic dominant, multiple anomaly syndrome, with an estimated incidence around 1-2/ 100000 worldwide. Not all of the affected individuals have the same malformations.

Five major criteria delineate KS: postnatal short stature, skeletal anomalies, moderate mental retardation, dermatoglyphic anomalies, characteristic facial dysmorphism [1].

\section{Case report}

We present the case of a 14 year girl diagnosed of the KS, refered to the Rehabilitation Service for kyphoscoliosis.

Searching in the literature, we didn't find reported the association with kyphosis, but only scoliosis and unspecific vertebral malformations.

The first referal to our service was on May 2010, when the patient is 14 years 10 months old. The clinical examination: occipito-sacral axis centred, plumbline of C7, T6, L4, S1 - 3/0/ 6.5/0 cm, Adam's Forward Bending test + (right rib cage elevated $2 \mathrm{~cm})$, Hamstring tightness. Finger-floor distancy $25 \mathrm{~cm}$.

The first Radiography: Hyperkyphosis $70^{\circ}$, Combined scoliosis T6-T12 $12^{\circ}$, T11-L4 10 , Risser 2.

A first corse was prescribed - Maria Adelaida type, without correction neither of the scoliosis nor of the hyperkyphosis. A second corse Cheneau type was tried, without satisfactory results, and then a third corse, Michel Alegre modified type without improvement. The physiotherapy treatment was also prescribed. Presently,

Hospital Germans Trias i Pujol, Badalona, Spain the case is to be evaluated by Raquis Unity Rehabilitation and Orthopedic Surgery.

\section{Conclusions}

Is the Kyphosis in our patient a characteristic of the Kabuki Syndrome? Is it a consecuence of the Growth Hormone therapy our patient followed for 24 month for the short stature? Or is it a Scheuermann Disease accidentaly associated with the Kabuki syndrome?

Published: 27 January 2012

\section{Reference}

1. Adam MP, Hudgins L: Kabuki syndrome: a review. Clin Genet 2005, 67(3):209-19.

\section{doi:10.1186/1748-7161-7-S1-P4}

Cite this article as: Taranu et al:: Case report of an adolescent girl with Kabuki syndrome and kyphoscoliosis, resistant at the conservative orthopedic treatment. Scoliosis 2012 7(Suppl 1):P4.

Submit your next manuscript to BioMed Central and take full advantage of:

- Convenient online submission

- Thorough peer review

- No space constraints or color figure charges

- Immediate publication on acceptance

- Inclusion in PubMed, CAS, Scopus and Google Scholar

- Research which is freely available for redistribution

(c) 2012 Taranu et al; licensee BioMed Central Ltd. This is an open access article distributed under the terms of the Creative Commons 